\title{
Toward the Third Millennium: One WWL(World Wide Language) via WCO(World Communication Organization)
}

\author{
Soon-bok Kim \\ Sejong University
}

\begin{abstract}
This paper is concerned with the vision of a world community in which the same global language, whether it is natural, artificial, or combinational, is used for communication and transfer of information. This includes concepts and principles of how such a goal can be achieved.

It is not intended to ignore or deny the fact that English in our times--by being the most widely used vehicle of global communication and intellectual discourse---connects the countries, languages, and cultures of our planet. It is, in fact, clearly recognized that along with Spanish, French, and Portuguese. English has a formidable impact over the existence of many societies and their way of thinking. In leading these other languages. English continues to routinely export, primarily through education, values of European culture and civilization to more than half of the world's countries.

It is not the aim of this paper to oppose the cultivation or preservation of any of some 6,000 to 7,000 existing oral languages. However, it is proposed that a way be found for making global communication easier and more accessible to everyone, particularly to those who are disadvantaged for whatever reasons. In many cases, it is political backwardness, lack of educational facilities, economic underdevelopment, regional impoverishment, or a combination of these (largely Third-World syndromes), something depriving large portions of various populations from adequate access to global communication and transfer of information. It is also proposed that this avenue be sought out in terms of economy,
\end{abstract}


rationality, and efficiency at the global level under philanthropic commissions of a world organization under a possible designation like WCO (World Communication Organization).

\section{Introduction}

At the threshold of the third millennium, the volume of international contacts is set to grow considerably. In the wake of further globalization, paralleled by expansion of information technology, and mounting international travel, the speed of international contacts is also likely to increase at an exponential rate, and so is the depth of contacts at many levels: economic, political, cultural.

While it is highly unlikely that two random travelers who meet at some place will speak some home language, it is ever more likely (and probably also necessary) that they rely on some third language for essential communications. Those who have traveled outside their own cultural and/or linguistic comfort zone are aware of the painful efforts at sign or body language, often meeting with mixed success, which are undertaken in the absence of translators or interpreters. Given this, the value of a true lingua franca becomes ever more apparent.

The use of a global language tends to place a certain social burden on societies, especially those which perceive such a trend as an infringement on their cultural domain. This burden may partly be identified in terms of internal stress; the business community in general and some of the media tend to support the use of foreign language(s), whereas the custodians of culture and home language and other conservative elements, foremost in rural areas, reject it as an invasion of sovereignty. They often denounce it, sometimes for political mileage, as a danger to the cultural or ethnic identity of their population. It seems that a mechanism is lacking which would allow for the unhindered use of a lingua franca (whether regionally or globally) while safeguarding the cultural and/or ethnic interests of 
a given society.

It is uncertain whether or not the creation of such a mechanism may have been on the agenda of those who began dappling in artificial languages at some point. It has been observed, nevertheless, that close to 1,000 artificial languages have been constructed with nearly all of them appearing since the early 17 th century (Dulicenko 1989). Such artificial languages, constructed on the basis of scientific and/or philosophical principles failed to win widespread support, and by the turn of the 20th century interest in them had largely disappeared. This was in part due to the circumstance that they were simply too complicated in structure to attract many learners. More fundamentally, perhaps, their scientific nature itself was flawed. The fact that neither the academic nor the business community would support them had sealed their fate.

The track record suggests that the use of artificial languages is consigned to the golden realm of the ivory tower where sterile theoretical debates on "back burner" issues are conducted in small obscure conference rooms. A major cause for this isolation is simply related to attitudes. While various widely used languages compete with each other, their proponents seem somehow united in their disaffection (if not contempt) for artificial languages. In their denouncement, the notion of "re-inventing the wheel" is customarily pressed into service, often in derision. Since language, conceptually and functionally, is a natural manifestation of culture and ethnicity, the deeply rooted tribal conscience of man clashes with the genius of abstract reasoning, which motivates the dabbling in artificial language. There does not seem to exist much motivation for a democratic approach to language use. The uncomplimentary sociopolitical history of colonialism provides food for sober reflection on this issue. Languages tend to either dominate others or are dominated by them, with hardly any middle field between these two extremes.

In the late nineteenth century, it was widely believed by many language planners that a common language shared by all peoples would eliminate many of the causes of friction between them. This 
idea resulted in the creation of an artificial language called Esperanto, developed in 1887 by the Polish physician L. L. Zamenhof(1859- 1917). As the twentieth century has shown, many intellectuals who associate linguistic diversity with national conflict have been proven right (Albert Gudrard 1945). The various conflicts between Greeks and Turks, between Turks and Armenians, between Germans and Poles or Czeches, between Basqes and Spaniards, between Latvians and Russians, or between Indians and Pakistanis are examples. Some of these conflicts are exacerbated by economic issues and/or religious differences. Examples are conflicts in the Middle East (Cyprus, Palestine) and also between England and Ireland.

A particularly relevant aspect of the dilemma resulting from the inherently divisive character of linguistic diversity in the political landscape is concerned with economics and relative social mobility. In a study entitiled Language Conflicts and Political Community (1967), R. F. Inglehart and M. Woodward discuss the effect of a "centrifugal force" which can be either strong or weak:

"An examination (...) suggests that political separatism is not inherent in the existence of linguistic pluralism (...). On the contrary, the centrifugal force which it exerts can be strong or weak, and is largely dependent on two related situational factors:

1. The level of economic and political development attained by the country in question.

2. The degree to which social mobility is blocked because of membership in a given language group...." (Inglehart \& Woodward 1967:359)

A conclusion to be drawn from this is that the higher the level of economic and political development attained in a country, the more sensitive the issue of relative social mobility between members of different language groups becomes.

On the other hand, political conflict is far from being restricted to 
political communities exposed to language-inspired differences; it needs to be pointed out that commonality of language and culture is no a safeguard against conflict. Aside from revolutions (e.g. French, Mexican, and Bolshevik), warfare, including civil conflict, can indeed occur between groups sharing a common language and culture, i. e. the War of 1812, the American Civil War (1861-1865), the Austrian-Prussian War (1866), the Spanish Civil War (19361939), the Korean Conflict (1950-1953), and the Bosnian Conflict (1993-1996) involving Serbs, Croats, and Muslims (all of whom use Serbo-Croatian and have lived in Bosnia for centuries).

The history of civilization shows that over considerable periods certain languages enjoyed popularity in their role as lingua franca in various regions of the globe. In the past, languages like Sanskrit, Persian or Quechua were in widespread use, and so was Latin (partly accompanied by Greek) which for over 1,000 years served the Europeans as their vehicle of intellectual discourse and held much sway over the development of European education as well as the formation of many modem languages. For better than 100 years, French was used as the international language of diplomats, business people, and bankers.

The multiplicity of languages is formidable and poses a hurdle for international communication and for peace, especially in areas where illiteracy rates are high. At this point, it is estimated that over 6,000 languages are spoken in the world (Grimes 1992:930). Some of these exist only orally. Certain tribal languages are nearing extinction, some in their written form, others completely. A large number of minor vernaculars in countries like Zambia and Namibia, for example, can survive only in the villages (in their oral form) where, unable to expand, they have entered a stage of terminal decay.

Other languages, especially Chose spoken in populous, wealthy countries with high educational standards, flourish by adding year after year millions of native speakers (or learners of acquired tongues) to their ranks. The most important of these is English which is the home language of at least 350 million people residing in about 750 countries (Crystal 1995). Far more significant is the 
fact that as many as 2 billion people may be able to communicate through English (Crystal 1995). English has been claimed to be the language of the media and of transportation, of navigation, of the information age, of international business, of diplomacy, and of youth culture, serving as the modem lingua franca, whether officially, semiofficially, or as a foreign language (Naisbitt 1989).

It should also be mentioned that Spanish is spoken by nearly 300 million native speakers (many of whom grow up bilingual) but that there are relatively few persons who speak it as an acquired tongue. The case of Chinese languages is interesting. They are spoken by over 1 billion native speakers but attract few learners who use them a foreign language. Furthermore, they do not receive much international attention at institutions of higher learning, in international business, or in the media.

What gives English the edge over other languages is its widespread use in four important scientific fields: bio science, medicine, chemistry, and food sciences. Moreover, the overwhelmingly dominant language used currently for Internet telecommunications is English (Cummings 1995). The distribution of publication languages shows that in 1990 publications in English had accounted for 76\% (Large 1995). This means that the other languages like German, French, Spanish, Russian, Japanese, Chinese, or Korean came to share the remaining $24 \%$. It is worthy of note that such western languages as German, French, Spanish, and Russian altogether decreased, while all oriental languages like Japanese, Chinese, and Korean increased in publications between 1970 and 1990.

At the close of the 20lh century, English is used widely in many different forums and settings. For example, at international conferences in all kinds of fields, irrespective of their venue, English is either the dominant language or, if not the official language, it is at least one of the languages used. Another important aspect is the use of English as the language of popular music and youth culture, particularly in Europe, sub-Saharan Africa, much of Latin America, and parts of coastal Asia. 
A great many experts claim nowadays, with more than a modicum of justification, that English by now has passed the critical point beyond which its future as a world language is assured. Although a major change in the political and/or economic balance of power in the world might affect the status of English, it is difficult to envision how any language (whether natural or artificial) is going to take its place in the next 50 to 100 years. As time goes by, English is likely to be seen not necessarily as the home language of a chosen few countries but as the property of everyone who chooses to learn it (Large 1995:29). This presupposes, of course, access at some level. Because of the fact that English is the most widely learned and/or acquired language, infiltrating many source languages, various types of English have developed in the world: Japlish, Konglish, Franglais, Spanglish, Sovanglisk, Hinglish, and so forth.

It has, however, been claimed that no matter how much English has become univeralized all over the world, people insist on keeping their traditional languages and cultures alive (Naisbitt 1989:145). Certain critics have been quite outspoken in regard to the cultural imperialist tendencies resulting from the diffusion of English since the end of the Second World War. Labels such as "Pax Anglica" or "Pax Americana" have been employed to denounce this trend (Phillipson and Skutnabb-Kangas 1996:439). Other terms are more recent. C. Hamelink (1994:110) speaks of "McDonaldization which involves production for global markets so that products and information aim at creating 'global customers that want global services by global suppliers'." This term is further identified as "aggressive round-the-clock marketing: the controlled information flows that do not confront people with the long term effects of an ecologically detrimental lifestyle, the competitive advantage against local cultural providers, the obstruction of local initiative, all converge into a reduction of local cultural space" (C. Hamelink 1994:112).

Doesn't the widespread use of English-across continents, languages, and cultures-apply almost exclusively (with the exception, perhaps, of English-speaking Africa) to those who are 
well learned and thus privileged socioeconomically? Doesn't one's access to (and thereby likelihood of) learning English determine one's personal access to world communications in the age of globalization and information online via a worldwide web?

What does someone feel who has the desire to communicate with the world's citizens, but who is handicapped by not knowing English (either because he did not grow up with it or was unable to learn it) but knows that English is essential in the promulgation of his message? He or she is in the role of the proverbial vox clamantis in deserto (the voice of someone calling in the wilderness: John 1:23). Should he or she give up on the desire of communicating and thereby risk being left out in the cold, or in the "desert" outside the world community? What about the equal human rights to free (and also effective) communication?

\section{Language Planning and Policy}

As pointed out above, there does not appear to exist much preparedness for democratically inspired fairness in the shaping of language policy and in the manner in which languages compete with each other around the globe. One almost becomes convinced that, for the most part, the "law of the jungle" is in operation. Although various national governments tend to appease (usually for political purposes) some of their minorities by endorsing different concepts of bilingual or multilingual education, the vast majority are concerned with traditional monolingual approaches toward their national language policy. Thus, the biased allocation of resources, along with corresponding idolization and glorification of the dominant language, as is routinely observed in monolingual language policy, is the norm.

However, at the threshold of the first century of the third millennium, i.e. the era of globalization and information, any responsible action toward world or international language planning should be carried out at the supranational or global level only. Such 
planning should be concerned with global processes of instruction, acquisition, and use of a world language that meets the basic requirements of linguistic simplicity and geopolitical neutrality while lending itself to being made accessible as widely as possible. It would have to be natural, artificial, and/or combinational in the sense that a potential "world language" accommodates natural languages and is to be planned based on global principles of economy, rationality, efficiency, and equal human rights. This global language planning and policy making must be performed from scratch independently of any influence of the international policymaking organizations that were established primarily to resolve economic and political conflicts and seek for cooperation across nations. Hence, there is a concrete need to prepare for and establish a planning and implementing body designed exclusively for work on a world language as a vehicle for global communication.

The EU members are involved in a great deal of supranational language planning in an environment where language is not only the medium but also a central sociopolitical concern. They had to resolve language issues in relation to language status, language requirements in employment, language use in transactions among integrated members (Labrie 1993). Language policies of the EU are more closely in line with multilingualism, and yet resulting in the diffusion of English as the sole European lingua franca. Fishman (1994:71) has concluded that "English can and will continue to be a mighty force in Europe even without becoming a dominant or domineering one."

Other international policy organizations like the UN, the World Bank, the International Monetary Fund, in which the U.S. exercise its mighty political and economic influence, all turn out to have facilitated the diffusion of English in carrying out their primary missions of international peace and trade across their member nations. Thus, they tend to reinforce the dominant position of English worldwide.

More recently established organizations such as WTO (World Trade Organization), NAFTA (North America Free Trade 
Association), APEC (Asia-Pacific Economic Cooperation), ASEAN (Association of South Eastern Asian Nations), ASEM, have to make use of some dominant languages (voluntarily or involuntarily) for communication in their business dealings. However, due to their exclusive focus on business and politics, they don't appear to be sufficiently qualified to deal with the aspect of professional language management. The international economic and/or political hierarchy should not be the hierarchy of languages for world communication for the world's community citizens.

However, Tsuada (1994), a Japanese communication scholar, has situated the diffusion of English within a wider range of language policy framework and alternative perceptions of what is at stake, and posits two global, contemporary language policy options: a diffusion- of-English paradigm and an ecology-of-language paradigm. The diffusion-of-English paradigm is characterized in terms of (1) capitalism, (2) science and technology, modernization, (4) ideological globalization and internalization, (5) transnationalization, (6) Americanization and homogenization of world culture, (7) linguistic, cultural, and media imperialism. The other paradigm of ecology of language is characterized in terms of (1) a human rights perspective, (2) equality in communication, (3) multilingualism, (4) maintenance of languages and cultures, (5) protection of national sovereignties, (6) promotion of foreign language education.

\section{Conclusion}

To fully appreciate the dilemma in which the world finds itself, one needs to consider one central hypothesis: What would we do nowadays if there were no global English, or if there were no global language at all? How would we go about our business on the international scene, especially in our dealings with distant regions of the world? How much in additional expenditure would it take just to train our diplomats, international bankers, businessmen, or 
researchers? What about crucial dialogue among nations on a global level? How would we bring rogue nations to heel if we had so many additional hurdles to jump in order to establish who supports or opposes whom, politically or economically? Would the world be a better or safer place without the prime link of communication which English provides, foremost in science, medicine, and education?

The question of balance seems to be on many minds. How shall we counter-balance the growing threat of being consumed by the champions of what Hamelink sees as the "McDonaldization" campaign? It would not serve the interests of the world community if certain countries, at on opportune moment, were to resort to radical policies to salvage what they, with more than enough justification, consider their home turf. Such a "back-lash" effect could prove disastrous. In many parts of the Middle East English is already denounced as the language of "Satan", even if the "global" mainstream media have good reason for not publicizing that fact beyond the level of token coverage. Such information is not deemed "fashionable" at this point and does not go down well with certain "peace process" policies.

With this in mind, the decision-making bodies of the world might be well-advised to consider the gradual development and introduction of an alternative, at least in part, to the near-exclusive use of English as the global language of communication. They can help with this global language issue by separating economic and political power from language or vice versa. The existing bodies can further provide international service by supporting an exclusively specialized and professional organization for world communication matters like World Communication Organization, as the GATT (General Agreement on Tarrifs and Trade) gave a rise to the WTO (World Trade Organization).

It should be noticed that a new civilization of communication is emerging in our times. This new civilization brings with it new styles of habit and transformed ways of working, loving, living, learning, and communicating that requires use of languages, both culturally and globally. Until now the human race has undergone 
great waves of change in literacy, i.e. literacy in home language and literacy in international languages as well as computer literacy. Much of this is reflected in first and second language acquisition and in the learning of major foreign languages. But now we must prepare ourselves for the days to come with a clear vision of the future global community in which the first language is spoken as a matter of culture, and a world language as a second language or lingua franca universalis, spoken for world communications across nations and cultures, and a foreign language of one's choice which is spoken as one's third language, possibly for the sake of expanding personal horizons and for the furtherance of aestheticism.

\section{References}

Guerard, A.L. 1945. Europe Free and United. Stanford:Stanford University Press.

Crystal, David. 1985. How many millions? The statistics of English today. EnglishToday 1,1.

Crystal, David. (1995). The Cambridge Encyclopedia of the English Language, New York:Cambridge University Press.

Cumming, J.D. 1995. The Internet and the English Language. English Today 11:1, 3-8.

Fishman, J.A. 1994a. On the limits of ethnographic democracy. In T. Skumabb-Kangas \& R. Philipson(Eds), Linguistic human rignt:over coming linguistic discrimination 49-61. Berlin: Mouton de Gruyter.

Fishman, J.A. 1994b. "English Only" in Europe? Some suggestion from an American perspective. Sociolinguistica 8, 65-72.

Grimes, Babara F. 1992. Ethnologue: amages of the world. 12th ed. 
Dallas summer Institute of Linguistics.

Hamelink, C. 1994. Trends in world communication: On disempowerment and self empowerment. Penang, Malaysia: Southboud \& Third World Network.

Inglehart, R.F. \& M. Woodward, 1967. Language conflicts and political community. Comparative Studies in Society and History 10, 27-40.

Labrie, N. 1993. La construction liguisrique de la Communaute Europenne [The linguistic composition of the European Community]. Paris:Honore Champion.

Large. A, 1965. The ArtificialLanguage Movement. Oxford:Blakwell.

Large. A, 1965. The Prospectsfor an International Language, (pp.22- 30)

Naisbitt, J. \& P. Aburdene. 1989. Ten New Directions for the 1990. Megatrends 2000. New York: William Morrow and Co., Inc.

Maisbit. J. 1994. Global Paradox. New York: William Morrow and Co., Inc.

Philipson, R. \& Skutnabb-Kangas, T. 1996. "English Only Worldwide or Language Ecology?" TESOL Quarterly. Volum 30 No.3 Autumn 1996.

Tsuda, Y. 1992. The dominance of English and linguistic discriminatnion. Media Development 16, 32-34.

Tsuada, Y. 1994. The diffusion of English: Its impact on culture and communication. Keio Communication Review 16,49-61. 